\title{
Groundwater Quality in an Upland Agricultural Watershed in the Sub-Humid Ethiopian Highlands
}

\author{
Adugnaw T. Akale1, Dessalegn C. Dagnew ${ }^{2}$, Shree Giri' ${ }^{3}$, Mulugeta A. Belete', Seifu A. Tilahun', \\ Wolde Mekuria4, Tammo S. Steenhuis ${ }^{1,3^{*}}$
}

\footnotetext{
${ }^{1}$ Faculity of Civil and Water Resources Engineering, Bahir Dar Institute of Technology, Bahir Dar University, Bahir Dar, Ethiopia ${ }^{2}$ Institut of Disaster Risk Management and Food Security Studies, Bahir Dar University, Bahir Dar, Ethiopia

${ }^{3}$ Department of Biological and Environmental Engineering, Cornell University, Ithaca, NY, USA

${ }^{4}$ International Water Management Institute (IWMI), East Africa and the Nile basin Office, Addis Ababa, Ethiopia

Email: *tss1@cornell.edu
}

How to cite this paper: Akale, A.T., Dagnew, D.C., Giri, S., Belete, M.A., Tilahun, S.A., Mekuria, W. and Steenhuis, T.S. (2017) Groundwater Quality in an Upland Agricultural Watershed in the Sub-Humid Ethiopian Highlands. Journal of Water Resource and Protection, 9, 1199-1212.

https://doi.org/10.4236/jwarp.2017.910078

Received: August 16, 2017

Accepted: September 27, 2017

Published: September 30, 2017

Copyright $\odot 2017$ by authors and Scientific Research Publishing Inc. This work is licensed under the Creative Commons Attribution International License (CC BY 4.0).

http://creativecommons.org/licenses/by/4.0/

cC)

\begin{abstract}
Agricultural intensification to meet the food needs of the rapidly growing population in developing countries is negatively affecting the water quality. In most of these countries such as Ethiopia, information on surface and especially groundwater quality is lacking. This limits the measure that can be taken to stop pollution. We, therefore, investigated the spatial and temporal variation of groundwater quality in the upland watershed. Tikur-Wuha watershed was selected because it is located in the Lake Tana watershed, which is seeing the first signs of eutrophication. Groundwater samples were collected from July 2014 to June 2015 from 19 shallow wells located throughout the watershed. Collected water samples were analyzed both in situ and in the laboratory to determine $\mathrm{pH}$, electric conductivity (EC) and total dissolved solid (TDS), concentration of chemicals (nitrate, dissolved phosphorus, calcium, magnesium, aluminum and iron) and Escherichia coli (E. coli). We found that shallow groundwater had greater chemical concentrations and E. coli level in the monsoon rain phase than in the dry phase. Wells located down slope exhibited greater concentrations than mid- and upper-slope positions, with the exception of the nitrate concentration that was less down slope, due to denitrification in the shallow groundwater. Only E. coli level was above the WHO drinking water quality standards. Further studies on groundwater quality should be carried out to understand the extent of groundwater contamination.
\end{abstract}

\section{Keywords}

E. Coli, Lake Tana, Nitrate, Phosphorus, Pollution 


\section{Introduction}

Groundwater is the most reliable source of drinking water in different parts of Africa [1]. It is available throughout the year and less contaminated than surface water because the rain is naturally filtered before it recharges the groundwater [2]. Despite this, studies in China [3], Turkey [4] and Portugal [5] have found that groundwater is contaminated with chemical and bacteriological contaminations due to anthropological factors such as dumping of industrial waste, improper waste management, application of fertilizers and pesticides [6] [7] [8].

Studies in Ethiopia have shown that groundwater is contaminated due to uncontrolled waste management, poor sanitation, poor management and use of fertilizers [9] [10] [11]. Samples collected from protected hand dug wells and developed springs located in the rural areas of Ethiopia showed that many wells have high level of E. coli [12] [13]. Similarly, a rapid assessment of drinking water quality in Ethiopia showed that the nitrate and fluoride concentration of more than $30 \%$ of water sources exceeded the WHO drinking water quality standards [14].

Cleanup of contaminated groundwater is cumbersome and costly [15]. Monitoring and detailed case studies of groundwater quality can provide an early warning system before cleanup is needed. Therefore, in this study, we investigated the spatial and temporal variation of shallow groundwater quality in the Tikur-Wuha watershed, Lake Tana basin where the first signs of eutrophication have been noted [16]. The Tikur-Wuha watershed was selected because it is typical for other watersheds in the highlands with intensive agriculture and the availability of shallow groundwater wells that provide water for household consumption.

\section{Materials and Methods}

\subsection{Description of the Study Area}

The study was conducted in the 1128 ha Tikur-Wuha watershed, situated in the upper Lake Tana basin of the Ethiopian highlands (Figure 1). Rainfall pattern of the watershed is mono-modal. More than $85 \%$ of the rainfall falls from May to September. The average annual rainfall from 2010 to 2015 was $1518 \mathrm{~mm}$. Mean daily temperature was $15^{\circ} \mathrm{C}$. The parent material is Tarmaber basalt rock and major soil type is Chromic Luvisols [17]. The steady state infiltration rate of the soil ranged from $7-117 \mathrm{~mm} \cdot \mathrm{hr}^{-1}$, with a median of $31 \mathrm{~mm} \cdot \mathrm{hr}^{-1}$. Based on a 10 -minute measured rainfall, only $6 \%$ of the rainfall intensity exceeded the median infiltration rate of the watershed. This indicates that most of the rain in the uplands infiltrated in to the soils and then either evaporated or flow as interflow and base flow from the top of the watershed to valley bottom and raising the water table close to surface during the rain phase of the monsoon. Rain on the saturated portions of the valley bottom became saturation excess runoff.

Seventy percent of the watershed, mainly on the mid slope and, to a lesser degree, on the upper slopes, is cropped with barley, wheat and potatoes during 


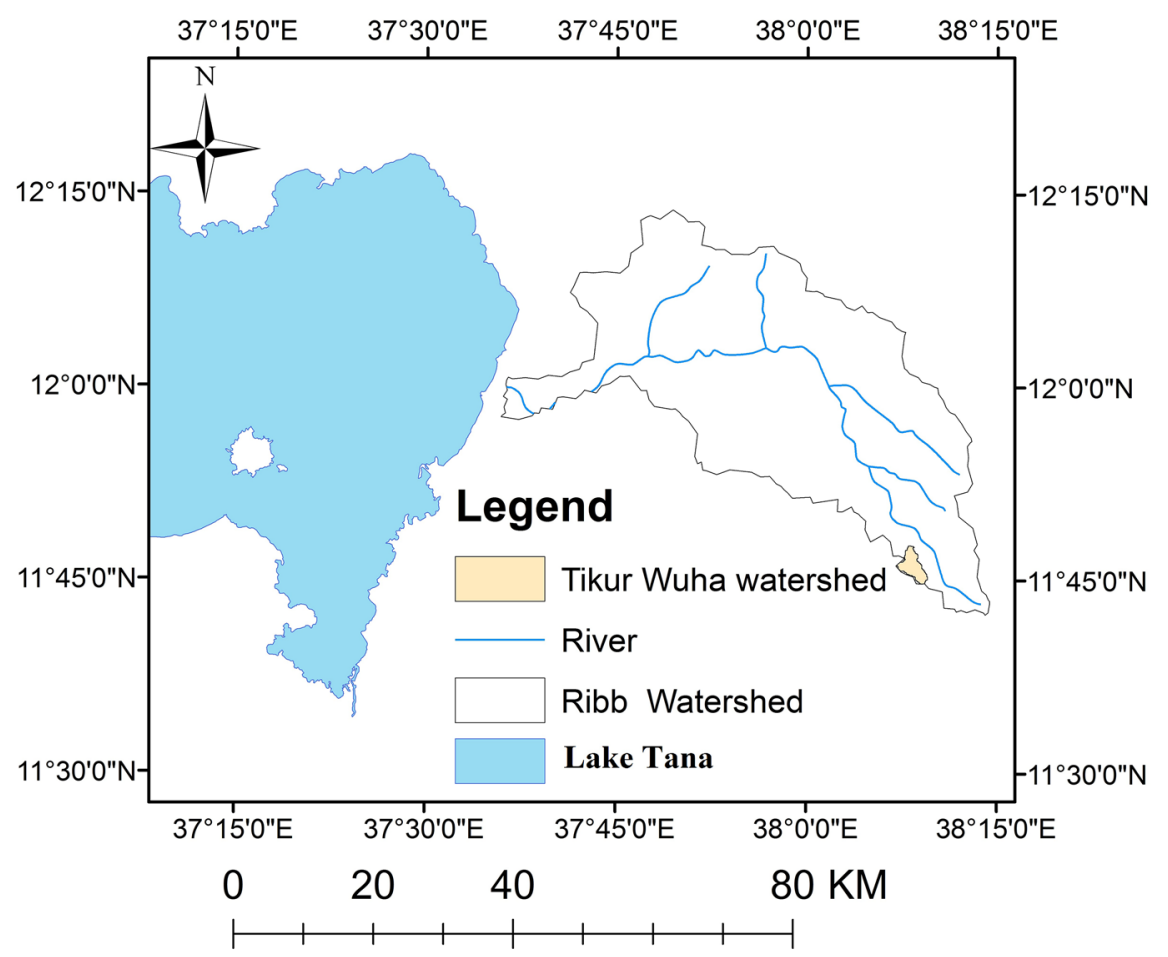

Figure 1. Location of Tikur-Wuha watershed in Ribb watershed that drains to Lake Tana.

rainy season. Bushes and shrubs that are located in the upslope, covers five percent of the watershed. Thirteen percent of the watershed is grassland on valley bottomland, with seasonally high groundwater and $12 \%$ consists of eucalyptus forest. The livelihood of the community largely depends on rain-fed agriculture. Commonly, the farmers use inorganic fertilizers like Urea composed of $45 \%$ $46 \%$ nitrogen and diammonium-phosphate that contains $18 \%-21 \%$ nitrogen and $46 \%-53 \% \mathrm{P}_{2} \mathrm{O}_{5}$. Households in the studied watershed obtain the drinking water from shallow groundwater.

\subsection{Groundwater Sampling and Laboratory Analyses}

Groundwater samples were collected from 19 wells located at three landscape positions (i.e. bottom, mid and up slope) (Figure 2, Figure 3). Well depths range from $5-13 \mathrm{~m}$. The water levels of the wells were measured during rain phase (August) and dry phase (February) using deep stick and tape meter. Water levels at three landscape (top, mid and bottom slope) was averaged for different seasons (dry and rainy). The samples were taken after 5 - 8 minutes of pumping. Samples were collected using a $500 \mathrm{ml}$ clear plastic jar with screw caps. Physical and chemical water quality characteristics were determined in samples taken monthly from July 2014 to June 2015. Bacteriological characteristics were analyzed in three-month intervals (i.e., September, December, March, and June). The water table depth was measured in August 2014 and February 2015. The collected samples were put in an icebox and transported to the laboratory for analyses within 24 hours. Samples were analyzed for pH, EC, TDS, nitrate 


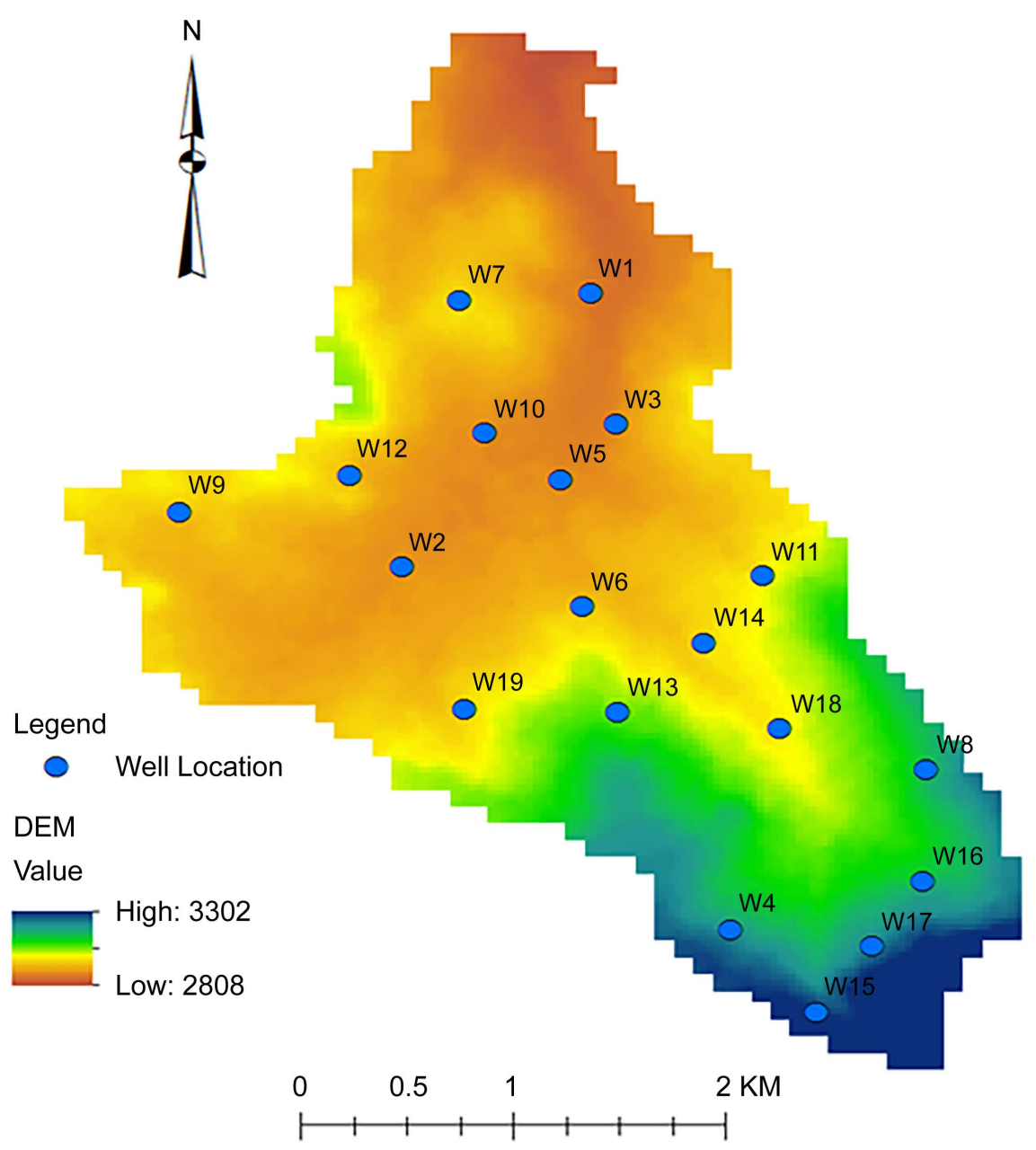

Figure 2. Location of wells for collecting water quality samples in the Tikur-Wuha watershed.

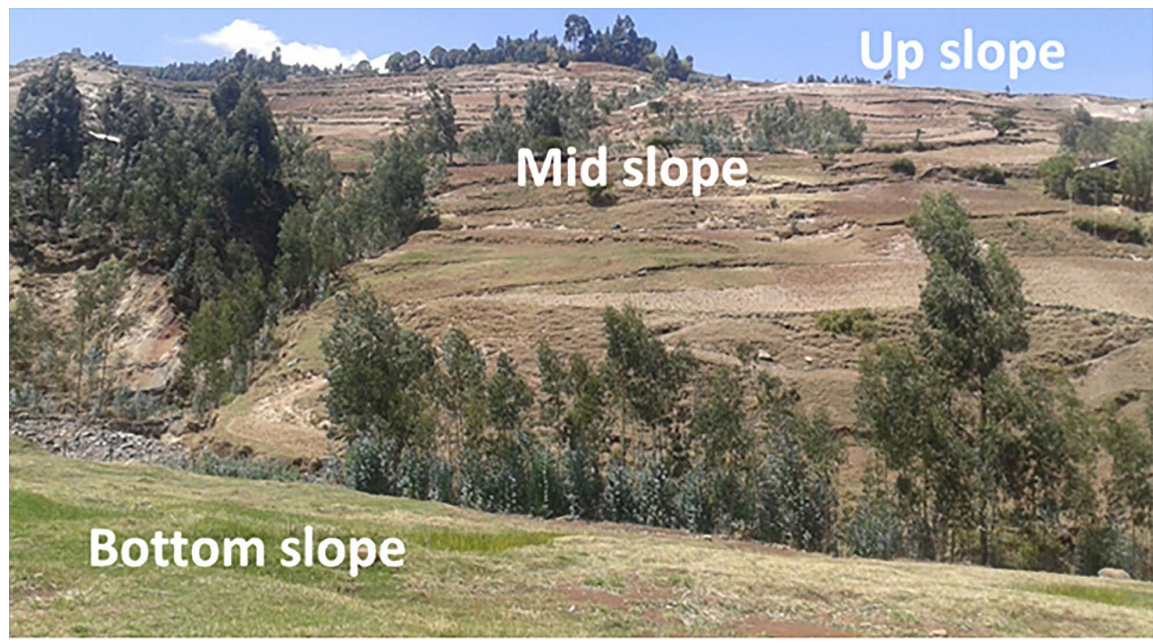

Figure 3. Photograph of Tikur-Wuha watershed depicting the three landscape positions: bottom slope or valley bottom; mid slope and up-slopes (Bottom slope of the watershed ranges from 2808 to $2996 \mathrm{~m}$, mid slope from 2996 to 3101 and up slope from 3101 to $3302 \mathrm{~m})$. 
$\left(\mathrm{NO}_{3}^{-}\right)$, calcium $(\mathrm{Ca})$, iron $(\mathrm{Fe})$, magnesium $(\mathrm{Mg})$, aluminum $(\mathrm{Al})$, phosphorus (P), and Escherichia coli (E. coli). TDS and EC were determined in situ using dissolved solid tester, while a portable $\mathrm{pH}$ meter was used to determine $\mathrm{pH}$. The dissolved ions species $\left(\mathrm{NO}_{3}^{-}, \mathrm{P}, \mathrm{Ca}, \mathrm{Mg}, \mathrm{Al}\right.$ and $\mathrm{Fe}$ ) were determined in the laboratory based on American Public Health Association's standard method [18] using a Plain test 7100 spectrophotometer with a detection limit of $0.001 \mathrm{mg} / \mathrm{L}$ [16].

The compartment bag test was used to determine the most probable number (MPN) of E. coli. The plastic bag contained internal compartments of different volumes, analogous to using a series of bottles or tubes of culture bacteria. The concentration of bacteria in the samples estimated from the combination of positive/negative compartments gave the most probable number of E. coli per 100 $\mathrm{mL}$.

\subsection{Statistical Analysis}

Following [18], data were analyzed using the IBM SPSS Statistics 20 software. Two-way multivariate analyses of ANOVA were used to determine the effect of season (wet and dry), and slope position on shallow groundwater quality. The data were checked for normality using the Shapiro-Francia test and homogeneity of variances using Leven's test. All tested parameters were normally distributed.

\section{Results and Discussion}

\subsection{Results}

Groundwater was shallower in the valley bottom than uphill (Figure 4, Table 1). In August, during the rainy phase, the average groundwater depth was $2.4 \mathrm{~m}$ for the wells located in the valley bottom, while $7.7 \mathrm{~m}$ for mid and $9.7 \mathrm{~m}$ for upper slope positions. In February, in the dry phase, the average water table depth was $5.4 \mathrm{~m}$ for the valley bottom whereas $9 \mathrm{~m}$ and $10 \mathrm{~m}$ deep for the mid and upslope

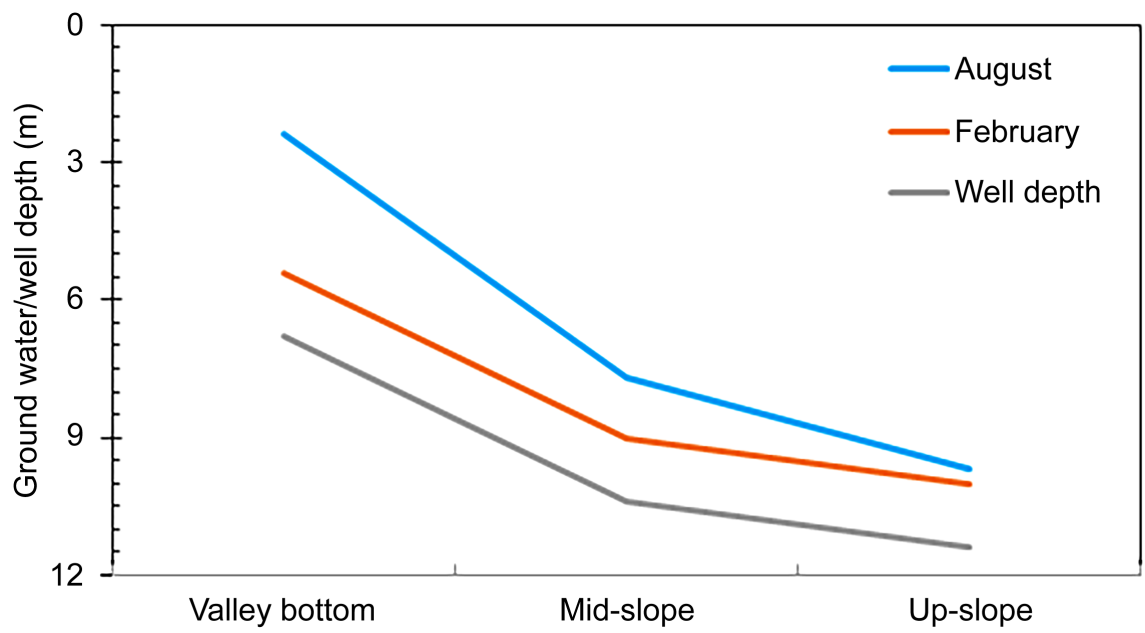

Figure 4. Average groundwater depth up slope, mid slope and in the valley boom in the Tikur-Wuha watershed at the end of the rain phase in August and near the end of the dry phase in February. 
position respectively. The temporal variation in groundwater depth was less in the upper slope position than downslope positions (Figure 4). The water levels in the wells in the valley bottoms rise to close to the surface during rainy phase and then decreased during the dry phase. Upslope the water levels were always deep and varied little throughout the year. The spatial and temporal variations of the shallow groundwater level was similar with other sub humid watersheds in the Ethiopian highlands [19] [20]. Table 3 showed that the average groundwater quality in the watershed. The water quality results were compared with WHO drinking water quality standards (Table 2, Table 3 ). The tested water quality parameters ( $\mathrm{Al}, \mathrm{P}, \mathrm{Fe}, \mathrm{Ca}, \mathrm{NO}_{3}^{-}$, TDS and $\mathrm{EC}$ ) are within the acceptable range for the drinking water.

The Al, $\mathrm{P}, \mathrm{Fe}, \mathrm{Ca}, \mathrm{NO}_{3}^{-}$, TDS and $\mathrm{EC}$ concentrations of wells were independent of landscape positions and greater in the rain monsoon phase from June to September than during the dry phase in the remainder of the year (Figure 5, Table 3). Based on the two-way multivariate analysis, concentration was significantly different $(p<0.05)$ between the dry and the rainy monsoon phase (Table 4). Spatially $\mathrm{P}, \mathrm{Ca}, \mathrm{Mg}, \mathrm{EC}$, and TDS were significantly greater $(p<0.05)$ at bottom slope positions than at mid- and upper-slope positions (Figure 5, Table 4).

Table 1. Groundwater level and depth of monitored wells of Tikur-Wuha watershed (August 2014 and February 2015 of Tikur-Wuha watershed).

\begin{tabular}{|c|c|c|c|c|}
\hline & & Bottom Slope & Mid Slope & Up Slope \\
\hline \multirow{3}{*}{$\begin{array}{l}\text { Groundwater level from } \\
\text { the surface (m) (August) }\end{array}$} & Average & 2.4 & 7.7 & 9.7 \\
\hline & Maximum & 4.5 & 10 & 11.5 \\
\hline & Minimum & 1.3 & 5.8 & 6.3 \\
\hline \multirow{3}{*}{$\begin{array}{l}\text { Groundwater level from } \\
\text { the surface }(\mathrm{m}) \text { (February) }\end{array}$} & Average & 5.4 & 9 & 10.0 \\
\hline & Maximum & 7.5 & 11.2 & 11.8 \\
\hline & Minimum & 3.5 & 7 & 6.5 \\
\hline \multirow{3}{*}{ Well depth (m) } & Average & 6.8 & 10.4 & 11.4 \\
\hline & Maximum & 9 & 13 & 13 \\
\hline & Minimum & 5 & 8.5 & 8 \\
\hline
\end{tabular}

Table 2. World health organization drinking water quality standards.

\begin{tabular}{cc}
\hline Parameters & Maximum WHO permissible limit \\
\hline $\mathrm{Al}$ & $0.2 \mathrm{mg} / \mathrm{L}$ \\
$\mathrm{Ca}$ & $75 \mathrm{mg} / \mathrm{L}$ \\
$\mathrm{Fe}$ & $0.3 \mathrm{mg} / \mathrm{L}$ \\
$\mathrm{Mg}$ & $50 \mathrm{mg} / \mathrm{L}$ \\
$\mathrm{NO}_{3}$ & $50 \mathrm{mg} / \mathrm{L}$ \\
$\mathrm{pH}$ & $6.5-8$ \\
$\mathrm{TDS}$ & $1000 \mathrm{mg} / \mathrm{L}$ \\
E. coli & 0 \\
\hline
\end{tabular}



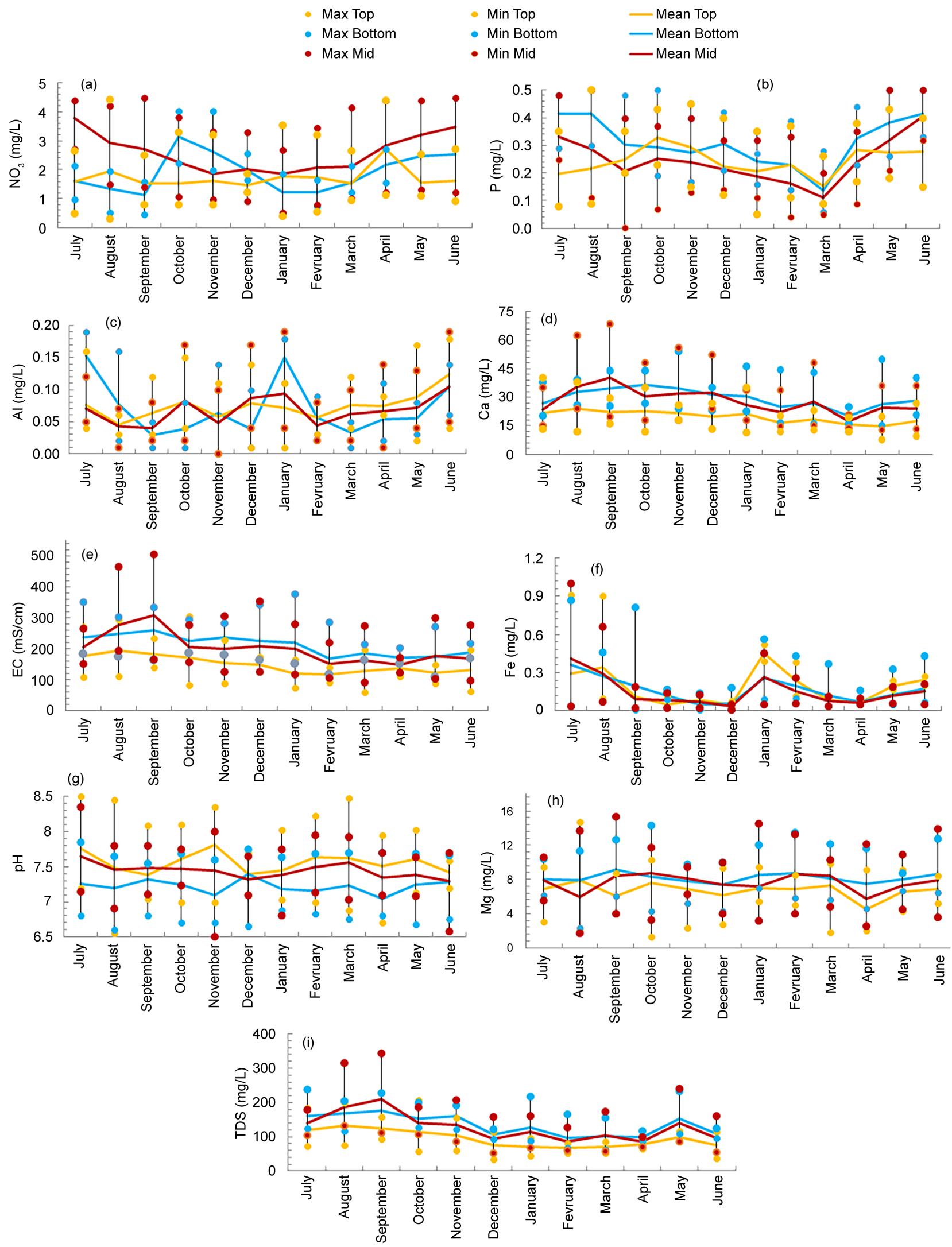

Figure 5. Shallow groundwater quality for the three slope positions of Tikur-Wuha watershed. (a) Nitrate-N, (b) Phosphorus, (c) Aluminum, (d) calcium, (e) Electrical conductivity (EC), (f) Iron, (g) pH, (h) Magnesium, (i) Total dissolved solids. 
Table 3. Average, maximum, minimum and standard error (S. E) of shallow groundwater quality for distinct wet and dry season in the Tikur-Wuha watershed (July 2014-June 2015).

\begin{tabular}{lllllllllll}
\hline Season & Statistics & $\mathrm{Al}(\mathrm{mg} / \mathrm{L})$ & $\mathrm{Ca}(\mathrm{mg} / \mathrm{L})$ & $\mathrm{EC}(\mu \mathrm{S} / \mathrm{cm})$ & $\mathrm{Fe}(\mathrm{mg} / \mathrm{L})$ & $\mathrm{Mg}(\mathrm{mg} / \mathrm{L})$ & $\mathrm{NO}_{3}(\mathrm{mg} / \mathrm{L})$ & $\mathrm{P}(\mathrm{mg} / \mathrm{L})$ & $\mathrm{pH}$ & $\mathrm{TDS}(\mathrm{mg} / \mathrm{L})$ \\
\hline \multirow{6}{*}{ Wet } & Average & 0.09 & 28.29 & 219.24 & 0.25 & 7.66 & 2.43 & 0.31 & 7.42 & 144.97 \\
& Maximum & 0.19 & 68.50 & 505.90 & 1.00 & 15.30 & 4.47 & 0.50 & 8.50 & 344.00 \\
& Minimum & 0.01 & 9.80 & 62.20 & 0.01 & 1.70 & 0.32 & 0.00 & 6.55 & 36.10 \\
& S. E & 0.01 & 1.25 & 8.99 & 0.03 & 0.34 & 0.13 & 0.01 & 0.05 & 6.41 \\
& Average & 0.06 & 25.27 & 175.68 & 0.13 & 7.52 & 2.01 & 0.24 & 7.40 & 109.39 \\
\multirow{6}{*}{ Dry } & Maximum & 0.17 & 56.00 & 376.30 & 0.57 & 14.50 & 4.40 & 0.50 & 8.48 & 240.40 \\
& Minimum & 0.00 & 8.00 & 59.50 & 0.01 & 1.30 & 0.41 & 0.04 & 6.50 & 34.50 \\
& S.E & 0.00 & 0.78 & 4.79 & 0.01 & 0.21 & 0.08 & 0.01 & 0.03 & 3.30 \\
\hline
\end{tabular}

Table 4. Seasonal and spatial two-way multivariate analysis of shallow groundwater quality of Tikur-Wuha watershed (July, 2014-June, 2015).

\begin{tabular}{ccccccccccc}
\hline & Source & $\mathrm{Al}$ & $\mathrm{Ca}$ & $\mathrm{EC}$ & $\mathrm{Fe}$ & $\mathrm{Mg}$ & $\mathrm{NO}_{3}$ & $\mathrm{P}$ & $\mathrm{pH}$ & $\mathrm{TDS}$ \\
\hline Season & $\mathrm{df}$ & 1 & 1 & 1 & 1 & 1 & 1 & 1 & 1 & 1 \\
& $\mathrm{~F}$ & 31.9 & 4.5 & 22.4 & 23.9 & 0.2 & 7.2 & 16.5 & 0.1 & 29.8 \\
& Sig. & $0.00^{*}$ & $0.03^{*}$ & $0.00^{\star}$ & $0.00^{\star}$ & 0.63 & $0.01^{*}$ & $0.00^{*}$ & 0.79 & $0.00^{*}$ \\
Slope & $\mathrm{df}$ & 2 & 2 & 2 & 2 & 2 & 2 & 2 & 2 & 2 \\
& $\mathrm{~F}$ & 2.0 & 18.9 & 18.6 & 0.4 & 4.3 & 22.4 & 10.9 & 12.1 & 15.2 \\
& Sig. & 0.14 & $0.00^{*}$ & $0.00^{*}$ & 0.64 & $0.01^{*}$ & $0.00^{*}$ & $0.00^{*}$ & $0.00^{*}$ & $0.00^{*}$ \\
\hline
\end{tabular}

*Significant at $p<0.05$.

In contrast, $\mathrm{NO}_{3}^{-}$concentrations were significantly greater at mid-slope positions than bottom and upper-slope positions (Table 4, Figure 5(a)).

The microbiological water quality of the groundwater was in Table 5. The results of the samples were compared with WHO water quality standards for drinking water (Table 5). Ninety percent of wells were contaminated with E. coli in the rain monsoon phase (i.e., September and June), which exceeds from WHO standard for drinking water. In the dry phase (i.e., December and March), $45 \%$ of the sampled wells $(n=19)$ were contaminated. Similar to most of the dissolved ion concentrations, E. coli contamination was more severe in the downslope than the upslope positions (Table 5).

\subsection{Discussion}

In general, the dissolved ions and $\mathrm{NO}_{3}^{-}$concentrations in groundwater (Figure 5, Table 3) were below WHO drinking water quality standards. This is in line with few other studies conducted in the Ethiopian highlands [12] [13] [21].

EC, (mainly mid-slope and valley bottom) and TDS of the sampled groundwater in the wet phase significantly exceeded that of the dry phase $(p<0.001$, Table 4, Figure 5(e), Figure 5(i)). In the rainy phase, the fertilizers and other 
Table 5. Spatial and temporal variation of microbiological water quality (E. coli) of shallow groundwater (September and December 2014 and March and June 2015).

\begin{tabular}{cccccc}
\hline Slope position & Month & September & December & March & June \\
\hline \multirow{3}{*}{ Bottom slope } & Number of samples & 6 & 6 & 6 & 6 \\
& Cree E. coli & 0 & 2 & 3 & 0 \\
& Contaminated samples with E. coli & 6 & 4 & 3 & 6 \\
\% polluted & $100 \%$ & $67 \%$ & $50 \%$ & $100 \%$ \\
Mid slope & Number of samples & 8 & 8 & 8 & 8 \\
& Cree E. coli & 1 & 5 & 7 & 0 \\
& Contaminated samples with E. coli & 7 & 3 & 1 & 8 \\
& \% polluted & $88 \%$ & $38 \%$ & $13 \%$ & $100 \%$ \\
Upper slope & Number of samples & 5 & 5 & 5 & 5 \\
& Contaminated samples with E. coli & 4 & 1 & 0 & 4 \\
& \% polluted & $80 \%$ & $20 \%$ & $0 \%$ & $80 \%$ \\
\hline
\end{tabular}

minerals from the surface dissolved and infiltrated into the groundwater. Some of the other elements related to fertilizer application follow this general trend as well, such as nitrate in the wells located in the upslope and mid-slope, but not in a wells located in valley bottom (orange and red lines and points in Figure 5(a)) and the phosphorus in the bottom and mid-slope wells (Figure 5(b)). Ca (especially the upland wells, Figure 5(d)) and magnesium (Figure 5(h)) remain relatively constant throughout the year while $\mathrm{Al}$ (Figure 5(c)) and Fe (Figure 5(f)) were elevated during some of the dry months, indicating that the sources of these four elements were in the subsurface and not a result of processes at the soil surface [22].

The TDS and EC concentrations at the upper slope position (Orange line in Figure 5(e), Figure 5(i)), were generally less than mid-slope and downslope because a relatively large portion of area was covered with shrubs [23]. The concentration of TDS (blue line and point in Figure 5(i)) and EC (blue in Figure $5(\mathrm{e})$ ) are slightly greater in the valley bottom (except during the end of rain monsoon phase in August and September) despite most agricultural activities taking place in mid-slope. The reason for the greater concentration during the dry phase, the groundwater level relatively shallow in the valley bottom and it can evaporate [24] that increased concentration. Groundwater depth on the other landscape position is too deep for evaporation. During the rain phase, concentration at mid slope are greater because salts in the cropland easily dissolved by the rainwater and infiltrating to the groundwater.

The trend of concentrations of the two dissolved nutrients $\left(\mathrm{NO}_{3}^{-}\right.$and $\left.\mathrm{P}\right)$ varies with slope position. Nitrate is greater at mid-slope position and phosphorus is greater at the valley bottom. However, both have the lowest concentration at the up-slope position (Figure 4). The greater nitrate concentration at mid-slope 
position can be explained by the existence of agricultural lands in the mid slope where applied fertilizers leached down to the groundwater [16] [25] [26] [27]. The saturated condition in the bottom slope position favors denitrification and contributes to the lower $\mathrm{NO}_{3}^{-}$content in shallow wells, located in the valley bottom [27] [28]. Similarly, [29] [30] [31] detected higher concentrations of nitrate in the parts of a watershed where croplands dominate, while lower concentrations of nitrate were detected at the bottom-slope positions of the watershed.

The greater $\mathrm{P}$ concentration at the bottom slope position is related to both sediments accumulation at the bottom slopes from the fertilized agricultural land [32] [33] and the water table being near the soil surface causing reduced soil conditions. Reduced conditions increases dissolved P [18] [32] [34] [35] [36]. In addition, grazing cattle defecating on the bottomlands may cause increases in $\mathrm{P}$ concentration. Some animals are also in the top part of the watershed and could explain the greater P concentrations. However, the manure is often collected as fuel and the ashes from the burned manure are applied to the cultivated land.

The primary source of the E. coli contamination is human and animal feces [37]. The contamination is most severe during the wet phase due to the leaching of the waste into shallow groundwater via preferential flow paths short-circuiting the surface with the groundwater. The greater contamination of E. coli in groundwater of the valley bottomlands (Table 5) is caused likely by the majority of the cattle grazing and defecating on those periodically saturated lands and thereby causing high levels of E. coli bacteria in the water recharging the groundwater [38].

The shallow groundwater is the response of the rainfall and any change in the rainfall will affect the ground water level and the water quality [39]. Similarly, [40] found that increase in rainfall increased human exposures to agricultural contaminants like waterborne pathogens. Nitrate concentrations in the valley bottom may increase when rainfall decreases because the groundwater might not rise to the surface reducing the effect of denitrifcation.

\section{Conclusion}

Groundwater quality in the Tikur-Wuha watershed at the headwaters of the Blue Nile in the Lake Tana basin was monitored. Shallow groundwater quality is influenced by landscape position, season and associated agricultural management practices. The concentration of dissolved ion species and E. coli level of groundwater is greater in the rainy season than in the dry season. The concentration of dissolved ion species and E. coli levels increased from the top of the watershed to the valley bottom of the watershed. However, nitrate concentration is an exception with greater values at the mid slope position than up slope and bottom slope of the watershed. The elevated concentrations of E. coli suggest that remedial action should be undertaken to improve groundwater quality that is a major source of drinking water in most developing regions of the world such as the Lake Tana watershed. From this study, we can conclude that installation 
of wells for water supply should consider the relationship of landscape position and water quality. In addition, water quality in wells should be monitored for the impact of agricultural inputs and any improvements due to best management practices.

\section{Acknowledgements}

The study was funded by the Blue Nile Water Institute, the Norman Borlaug Fellowship Program, with the logistics support from Bahir Dar University and Cornell University. We are grateful for Eshetu Assefa, Osman and Worku for their assistance during laboratory work and Peggy Stevens for editing the manuscript.

\section{References}

[1] MacDonald, A.M. and Davies, J. (2000) A Brief Review of Groundwater for Rural Water Supply in Sub-Saharan Africa. British Geological Survey Technical Report WC/00/33, BGSKEY, Worth, UK.

[2] Nwobodo, T.N., Anikwe, M.A.N. and Chukwu, K.E. (2015) Assessment of Spatio-Temporal Variation of Groundwater Quality in Udi-Ezeagu Watershed, Enugu Area, Southeastern Nigeria. International Journal of Environmental Monitoring and Analysis, 3, 210-217. https://doi.org/10.11648/j.ijema.20150304.12

[3] Wu, J. and Sun, Z. (2016) Evaluation of Shallow Groundwater Contamination and Associated Human Health Risk in an Alluvial Plain Impacted by Agricultural and Industrial Activities, Mid-West China. Exposure and Health, 8, 311-329.

[4] Baba, A. and Tayfur, G. (2011) Groundwater Contamination and Its Effect on Health in Turkey. Environmental Monitoring and Assessment, 183, 77-94. https://doi.org/10.1007/s10661-011-1907-z

[5] Barroso, M.F., Ramalhosa, M.J., Olhero, A., Antão, M.C., Pina, M.F., Guimarães, L. and Chaminé, H.I. (2015) Assessment of Groundwater Contamination in an Agricultural Peri-Urban Area (NW Portugal): An Integrated Approach. Environmental Earth Sciences, 73, 2881-2894. https://doi.org/10.1007/s12665-014-3297-3

[6] Kim, Y.J., Steenhuis, T.S. and Nam, K. (2008) Movement of Heavy Metals in Soil through Preferential Flow Paths under Different Rainfall Intensities. CLEAN-SOIL AIR WATER, 36, 984-989. https://doi.org/10.1002/clen.200800141

[7] Kurtz, M.P., Peikert, B., Brühl, C., Dag, A., Zipori, I., Shoqeir, J.H. and Schaumann, G.E. (2015) Effects of Olive Mill Wastewater on Soil Microarthropods and Soil Chemistry in Two Different Cultivation Scenarios in Israel and Palestinian Territories. Agriculture, 5, 857-878. https://doi.org/10.3390/agriculture5030857

[8] Leroux, E., Gomez, E., Monget, J.M., Viavattene, C., Viennot, P., Ducharne, A., Benoît, M., Mignolet, C., Schott, C. and Mary, B. (2007) Agriculture and Groundwater Nitrate Contamination in the Seine Basin. The STICS-MODCOU Modeling Chain. Science of the Total Environment, 375, 33-47. https://doi.org/10.1016/j.scitotenv.2006.12.002

[9] Alemayehu, T. (2004) The Impact of Uncontrolled Waste Disposal on Surface Water Quality in Addis Ababa, Ethiopia. SINET: Ethiopian Journal of Science, 24, 93-104. https://doi.org/10.4314/sinet.v24i1.18177

[10] Beyene, A., Addis, T., Kifle, D., Legesse, W., Kloos, H. and Triest, L. (2009) Comparative Study of Diatoms and Macroinvertebrates as Indicators of Severe Water 
Pollution: A Case Study of the Kebena and Akaki Rivers in Addis Ababa, Ethiopia. Ecological Indicators, 9, 381-392.

[11] Duguma, B., Tegegne, A. and Hegde, B.P. (2012) Assessment of the Effect of Season and Location on Microbiological and Physicochemical Quality of Livestock Drinking Water in Ginchi Watershed, Ethiopia. Global Veterinaria, 8, 342-346.

[12] Tsega, N., Sahile, S., Kibret, M. and Abera, B. (2014) Bacteriological and Physicochemical Quality of Drinking Water Source in a Rural Community of Ethiopia. African Health Sciences, 13, 1156-1161. https://doi.org/10.4314/ahs.v13i4.42

[13] Mengesha, A., Wubshet, M. and Gelaw, B. (2004) A Survey of Bacteriological Quality of Drinking Water in North Gondar. The Ethiopian Journal of Health Development, 18, 112-115.

[14] Dagnew, T., Assefa, D., Woldemariam, G., Solomon, F. and Schmoll, O. (2007) Rapid Assessment of Drinking-Water Quality in the Federal Republic of Ethiopia. The Federal Democratic Republic of Ethiopia, Ministry of Health, Environmental Health Department, Country Report, Addis Ababa.

[15] Hasan, S. (2014) Effect of Climate Change on Groundwater Quality for Irrigation Purpose in a Limestone Enriched Area. Doctoral Dissertation.

[16] Moges, M.A., Tilahun, S.A., Ayana, E.K., Moges, M.M., Gabye, N., Giri, S. and Steenhuis, T.S. (2016) Non-Point Source Pollution of Dissolved Phosphorus in the Ethiopian Highlands: The Awramba Watershed near Lake Tana. Clean-Soil, Air, Water, 44, 703-709. https://doi.org/10.1002/clen.201500131

[17] Kebede, S., Travi, Y., Alemayehu, T. and Ayenew, T. (2005) Groundwater Recharge, Circulation and Geochemical Evolution in the Source Region of the Blue Nile River, Ethiopia. Applied Geochemistry, 20, 1658-1676.

[18] Apha, A. (2012) WEF Standard Methods for the Examination of Water and Wastewater. 22nd Edition, American Public Health Association, Washington.

[19] Tilahun, S.A., Ayana, E.K., Guzman, C.D., Dagnew, D.C., Zegeye, A.D., Tebebu, T.Y., Steenhuis, T.S., et al. (2016) Revisiting Storm Runoff Processes in the Upper Blue Nile Basin: The Debre Mawi Watershed. Catena, 143, 47-56.

[20] Moges, M.A., Schmitter, P., Tilahun, S.A., Langan, S., Dagnew, D.C., Akale, A.T. and Steenhuis, T.S. (2017) Suitability of Watershed Models to Predict Distributed Hydrologic Response in the Awramba Watershed in Lake Tana Basin. Land Degradation \& Development, 28, 1386-1397. https://doi.org/10.1002/ldr.2608

[21] Liu, W., Xu, X., McGoff, N.M., Eaton, J.M., Leahy, P., Foley, N. and Kiely, G. (2014) Spatial and Seasonal Variation of Dissolved Organic Carbon (DOC) Concentrations in Irish Streams: Importance of Soil and Topography Characteristics. Environmental Management, 53, 959-967. https://doi.org/10.1007/s00267-014-0259-1

[22] Ayenew, T. (2006) Major Ions Composition of the Groundwater and Surface Water Systems and Their Geological and Geochemical Controls in the Ethiopian Volcanic Terrain. SINET: Ethiopian Journal of Science, 28, 171-188. https://doi.org/10.4314/sinet.v28i2.18253

[23] Laluraj, C.M., Gopinath, G. and Dineshkumar, P.K. (2005) Groundwater Chemistry of Shallow Aquifers in the Coastal Zones of Cochin, India. Applied Ecology and Environmental Research, 3, 133-139. http://drs.nio.org/drs/handle/2264/897 https://doi.org/10.15666/aeer/0301_133139

[24] Enku, T., Melesse, A.M., Ayana, E.K., Tilahun, S.A., Abate, M. and Steenhuis, T.S. (2016) Groundwater Evaporation and Recharge for a Floodplain in a Sub-Humid Monsoon Climate in Ethiopia. Land Degradation \& Development. 
[25] Liu, G.D., Wu, W.L. and Zhang, J. (2005) Regional Differentiation of Non-Point Source Pollution of Agriculture-Derived Nitrate-Nitrogen in Groundwater in Northern China. Agriculture, Ecosystems \& Environment, 107, 211-220.

[26] Flores-López, F., Easton, Z.M., Geohring, L.D. and Steenhuis, T.S. (2011) Factors Affecting Dissolved Phosphorus and Nitrate Concentrations in Ground and Surface Water for a Valley Dairy farm in the Northeastern United States. Water Environment Research, 83, 116-127. https://doi.org/10.2175/106143010X12681059116770

[27] Bayabil, H.K., Tilahun, S.A., Collick, A.S., Yitaferu, B. and Steenhuis, T.S. (2010) Are Runoff Processes Ecologically or Topographically Driven in the (sub) Humid Ethiopian Highlands? The Case of the Maybar Watershed. Ecohydrology, 3, 457-466. https://doi.org/10.1002/eco.170

[28] Tilahun, S.A. (2012) Observations and Modeling of Erosion from Spatially and Temporally Distributed Sources in the (semi) Humid Ethiopian Highlands. PhD Dissertation, Cornell University, Ithaca.

[29] Ogawa, A., Shibata, H., Suzuki, K., Mitchell, M.J. and Ikegami, Y. (2006) Relationship of Topography to Surface Water Chemistry with Particular Focus on Nitrogen and Organic Carbon Solutes within a Forested Watershed in Hokkaido, Japan. Hydrological Process, 20, 251-265. https://doi.org/10.1002/hyp.5901

[30] Vidon, P.G. and Hill, A.R. (2004) Landscape Controls on Nitrate Removal in Stream Riparian Zones. Water Resources Research, 40. https://doi.org/10.1029/2003WR002473

[31] Cooper, J.R., Gilliam, J.W., Daniels, R.B. and Robarge, W.P. (1987) Riparian Areas as Filters for Agricultural Sediment. Soil Science Society of America Journal, 51, 416-420. https://doi.org/10.2136/sssaj1987.03615995005100020029x

[32] Hively, W.D., Bryant, R.B. and Fahey, T.J. (2005) Phosphorus Concentrations in Overland Flow from Diverse Locations on a New York Dairy Farm. Journal of Environmental Quality, 34, 1224-1233. https://doi.org/10.2134/jeq2004.0116

[33] Dong, S., Liu, B., Liu, H., Wang, S. and Wang, L. (2014) Impacts of Groundwater Recharge from Rubber Dams on the Hydrogeological Environment in Luoyang Basin, China. The Scientific World Journal, 14, Article ID: 183457.

[34] Johnson, H.P., Baker, J.L., Shrader, W.D. and Laflen, J.M. (1979) Tillage System Effects on Sediment and Nutrients in Runoff from Small Watersheds. Transactions of the ASAE, 22, 1110-1114. https://doi.org/10.13031/2013.35165

[35] Obour, A.K., Vendramini, J.M.B., Silveira, M.L., Sollenberger, L.E., O’Connor, G.A. and Jawitz, J.W. (2011) Phosphorus Fertilization Responses on Bahiagrass Pastures: Forage Production and Water Quality. Agronomy Journal, 103, 324-330. https://doi.org/10.2134/agronj2010.0330

[36] Khan, F., Hayat, Z., Ahmad, W., Ramzan, M., Shah, Z., Sharif, M., Mian, I.A. and Hanif, M. (2013) Effect of Slope Position on Physicochemical Properties of Eroded Soil. Soil Environ, 32, 22-28.

[37] Gerba, C.P. and Smith, J.E. (2005) Sources of Pathogenic Microorganisms and Their Fate during Land Application of Wastes. Journal of Environmental Quality, 34, 42-48.

[38] Solomon, E.B., Yaron, S. and Matthews, K.R. (2002) Transmission of Escherichia coli O157: H7 from Contaminated Manure and Irrigation Water to Lettuce Plant Tissue and Its Subsequent Internalization. Applied and Environmental Microbiology, 68, 397-400. https://doi.org/10.1128/AEM.68.1.397-400.2002

[39] Gómez, E., Barmen, G. and Rosberg, J.E. (2016) Groundwater Origins and Circulation Patterns Based on Isotopes in Challapampa Aquifer, Bolivia. Water, 8, 207. 
https://doi.org/10.3390/w8050207

[40] Boxall, A.B., Hardy, A., Beulke, S., Boucard, T., Burgin, L., Falloon, P.D., Haygarth, P.M., Hutchinson, T., Kovats, R.S., Leonardi, G. and Levy, L.S. (2009) Impacts of Climate Change on Indirect Human Exposure to Pathogens and Chemicals from Agriculture. Environmental Health Perspectives, 117, 508.

https://doi.org/10.1289/ehp.0800084

Submit or recommend next manuscript to SCIRP and we will provide best service for you:

Accepting pre-submission inquiries through Email, Facebook, LinkedIn, Twitter, etc. A wide selection of journals (inclusive of 9 subjects, more than 200 journals)

Providing 24-hour high-quality service

User-friendly online submission system

Fair and swift peer-review system

Efficient typesetting and proofreading procedure

Display of the result of downloads and visits, as well as the number of cited articles

Maximum dissemination of your research work

Submit your manuscript at: http://papersubmission.scirp.org/

Or contact jwarp@scirp.org 